УДК 378.147.091.33-027.22:796.012.656

DOI https://doi.org/10.26661/2522-4360-2021-2-25

\title{
ІННОВАЦЙНІ ТЕХНОЛОГІЇ ФОРМУВАННЯ ПРОФЕСІЙНОЇ КУЛЬТУРИ МАЙБУТНІХ УЧИТЕЛІВ СПОРТИВНО-ХОРЕОГРАФІЧНИХ ДИСЦИПЛІН
}

\author{
Шевченко О. В. \\ кандидат педагогічних наук, доцент, \\ дочент кафедри теорії і методики фізичного виховання \\ Центральноукраӥнський державний педагогічний університет \\ імені Володимира Винниченка \\ вул. Шевченка, 1, Кропивницький, Украӥна \\ orcid.org/0000-0002-9493-348X \\ gymnast.olga@gmail.com
}

\author{
Ключові слова: професійна \\ культура, інновачї, \\ хореографія, фізична \\ культура, вчитель, студенти.
}

У статті обгрунтовуються шляхи формування професійної культури в майбутніх учителів спортивно-хореографічних дисциплін інноваційними засобами фізичної культури, спорту і мистецтва. 3'ясовано, що студенти під час навчання в закладі загальної середньої освіти повинні долучатися до процесу формування професійної культури на усвідомленому рівні, а потім вдосконалювати іiі для досягнення більш високих результатів у професійній діяльності. Доведено, що провадження інноваційних технологій у сучасну освіту суттєво прискорює передавання знань i накопиченого технологічного та соціального досвіду людства не тільки від покоління до покоління, а й від однієї людини до іншої. Сучасні інноваційні технології, підвищуючи якість навчання й освіти, дають змогу особистості успішніше й швидше адаптуватися до навколишнього середовища, соціально-економічних змін, сприяють розвитку інноваційного мислення та креативності. Освітні інновації вишу полягають у сучасному моделюванні, організації нестандартних лекційних та практичних занять; індивідуалізації засобів навчання; розробці нової системи контролю оцінки знань; застосуванні комп'ютерних, мультимедійних технологій, навчально-методичної продукції нового покоління. У підготовці майбутнього вчителя особливе місце посідає формування педагогічної культури. Лише в культурному середовищі можуть сформуватися фахівці, здатні вільно й широко мислити, створювати інтелектуальні цінності, яких завжди потребує школа, суспільство загалом. Культура $є$ підгрунтям формування особистості педагога. На думку науковців, неможливо опанувати будь-яку професію без всебічного розвитку особистості, фізичного, морального, духовного тощо. Доведено, що розробка нових науково-методичних засад у галузі вищої хореографічної освіти належить до актуальних проблем загальної естетичної культури та вимагає подальшої розробки та удосконалення теоретичного курсу з опанування студентами психологопедагогічних компонентів в освітній діяльності. Сприятливими умовами для набуття майбутніми педагогами професійного педагогічного досвіду $\epsilon$ проведення майстер-класів, що передбачає набуття студентами можливості ознайомитися 3 різними формами подачі матеріалу, сформувати уявлення про поліваріативність методик проведення занять, здійснити їх порівняльний аналіз, узагальнення, визначити шляхи формування власної методики викладання спортивно-хореографічних дисциплін з урахуванням передового педагогічного досвіду. 


\title{
INNOVATIVE TECHNOLOGIES OF FORMATION OF PROFESSIONAL CULTURE OF FUTURE TEACHERS OF SPORTS AND CHOREOGRAPHIC DISCIPLINES
}

\author{
Shevchenko O. V. \\ Candidate of Pedagogical Sciences, Associate Professor, \\ Associate Professor at the Department of Theory and Methods of Physical Education \\ Volodymyr Vynnychenko Central Ukrainian State Pedagogical University \\ Shevchenko str., 1, Kropyvnytskyi, Ukraine \\ orcid.org/0000-0002-9493-348X \\ gymnast.olga@gmail.com
}

Key words: professional culture, innovations, choreography, physical culture, teacher, students.
The article substantiates the ways of formation of professional culture in future teachers of sports and choreographic disciplines by innovative means of physical culture, sports and art. It was found that students in general secondary education should be involved in the process of forming a professional culture at a conscious level, and then improve it to achieve better results in professional activities. It is proved that the implementation of innovative technologies in modern education significantly accelerates the transfer of knowledge and accumulated technological and social experience of mankind not only from generation to generation, but also from one person to another. Modern innovative technologies, improving the quality of education and training, allow individuals to adapt more successfully and quickly to the environment, socio-economic changes, promote the development of innovative thinking and creativity. Educational innovations of the university are modern modeling, organization of non-standard lectures and practical classes; individualization of teaching aids; development of a new control system for knowledge assessment; application of computer, multimedia technologies; educational and methodical products of the new generation. In the training of future teachers a special place is occupied by the formation of pedagogical culture. Only in the cultural environment can specialists be formed who are able to think freely and widely, to create intellectual values, which are always needed by the school and society as a whole. Culture is the basis for the formation of the teacher's personality. According to scientists, it is impossible to master any profession without the comprehensive development of personality, physical, moral, spiritual, and so on. It is proved that the development of new scientific and methodological principles in the field of higher choreographic education is one of the current problems of general aesthetic culture and requires further development and improvement of the theoretical course for students to master psychological and pedagogical components in educational activities. Favorable conditions for future teachers to gain professional pedagogical experience are master classes, which provide students with the opportunity to get acquainted with different forms of presentation of material, to form an idea of the versatility of teaching methods, their comparative analysis, generalization, identify ways to form their own teaching methods, choreographic disciplines taking into account the advanced pedagogical experience.
Постановка проблеми. Важлива складова частина фахової соціалізації людини - формування в неї професійної культури, яку можна характеризувати як вираження зрілості та розвиненості системи соціально значущих особистісних якостей, які реалізовується у фаховій діяльності [4].

Сучасна наука розглядає процес становлення особистості нерозривно з розвитком особистісних якостей людини, пошуками свого місця в соціумі, становлення самокритичності і вимог до себе, що в результаті трансформуються до пошуку професійного шляху особистості, iii становлення як професіонала.

Формування особистості, що володіє високою професійною культурою, здатна до активної педагогічної діяльності, є невід'ємною частиною підготовки майбутнього фахівця. Вирішення цього завдання залежить від принципів організації 
цілісного педагогічного процесу, який виводить підготовку майбутнього педагога на особистісний рівень, поєднуючи професійну готовність і загальну культуру особистості. Система вищої освіти, що займається підготовкою професіональних кадрів, повинна приділяти увагу цілеспрямованому формуванню професійної культури фахівця. Доцільно, щоб студенти у процесі навчання у вузі починали долучатися до процесу формування професійної культури на усвідомленому рівні, надалі вони могли б ії вдосконалювати для досягнення більш високих результатів у професійній діяльності.

На формування професійної культури впливають особливості самої професії. Залежно від обраної професії особистість засвоює різні моделі поведінки, тому по-різному виявляється сутність професійної культури як здатності використовувати засвоєні знання, уміння, навички та досвід у розв'язанні типових і нестандартних завдань, що пов'язані з конкретним видом праці [3].

Професійна культура, на думку В. Радула, є характеристикою рівня, якості та цілісності професійної підготовки особистості. Загальний стан соціуму, як ми вже зазначали вище, безумовно має значний вплив на якість професійної культури. Саме тому високий рівень професійної культури $€$ свідченням розвинутого суспільства. Професійне становлення фахівців, вчителів і педагогів не розглядають із точки зору індивідуального розвитку особистості, тому що професійна культура фахівця $\epsilon$ дзеркалом його професіоналізму. Неможливо опанувати будь-яку професію без всебічного розвитку особистості, фізичного, морального, духовного тощо. Показником рівня розвитку професійної культури особистості є сформована система цінностей, моральності, цілісності особистості, професійних якостей та соціальної зрілості [7].

Н. Мойсеюк дав визначення поняттю культура: це сукупність матеріальних і духовних цінностей людства, які зроблені всіма видам діяльності людини. Сама людина формується у процесі власної діяльності як культурно-історична істота, що засвоює мову, прилучається до традицій і цінностей, що існують у суспільстві, оволодіє властивими для конкретного суспільства і його культури прийомами і навичками діяльності. Людина є продуктом загальнолюдської культури, іiї представником і носієм [6].

Наукові розвідки Л. Андрощук, О. Барабаш, О. Бережної, Т. Благової, Н. Буль, О. Бурлі, Ю. Богачової, О. Бондаренко, Ю. Волкової, Ю. Герасимової, Н. Добролюбової, Д. Корабельникової, С. Куценко, Л. Макарової, О. Мартиненко, Т. Мацаренко, Л. Мітакович, В. Никитина, Т. Осипової, О. Палилей, Г. Полякової, Ю. Ростовської, Т. Сердюк, О. Таранцевої, В. Шеремети,
Ю. Шмакової, А. Чернишової, Т. Фурманової, М. Юр'євої та інших авторів охоплюють широкий спектр проблем професійної підготовки фахівців-хореографів. Проблема підготовки майбутніх учителів до професійної діяльності хвилювала не одне покоління науковців, а саме видатних діячів: П. Блонського, І. Гербарта, О. Макаренка, I. Песталоцці, К. Ушинського, С. Шацького та ін. У працях видатних фахівців педагогіки В. Горової, Л. Митіна, В. Радула В. Сластеніна, та ін. виділена структура педагогічної діяльності та шляхи іiі становлення.

Науковці схиляються до того, що загальну культуру особистості розглядають як результат діяльності та розвитку людини. Тому вчені пов'язують два поняття разом - «людина» та «діяльність», професіоналізм особистості має ті властивості, які містять високий рівень ефективності для професійної діяльності.

Метою статті $\epsilon$ визначення змісту формування професійної культури майбутніх учителів спортивно-хореографічних дисциплін у системі вищої педагогічної освіти.

Виклад основного матеріалу дослідження. Аналіз науково-педагогічної літератури дозволив 3'ясувати, що лише в культурному середовищі можуть сформуватися фахівці, здатні вільно й широко мислити, створювати інтелектуальні цінності, яких завжди потребує школа, суспільство загалом. Культура $є$ підгрунтям формування особистості педагога. Ми погоджуємося 3 думкою М. Бабич та С. Вітвицької [1] відносно складових частин педагогічної культури як прояву творчої індивідуальності педагога:

- ерудиція, наукові знання, науковий світогляд;

- комунікативна культура;

- психолого-педагогічна та методична підготовка, педагогічна майстерність;

- особистісні якості (духовне багатство, гуманізм, справедливість, толерантність, відкритість, оптимізм, прагнення до самовдосконалення);

- розвинуте професійно-педагогічне мислення, професійна компетентність;

- педагогічна техніка (як сукупність прийомів володіння собою і прийомів впливу на інших вербальними і невербальними засобами).

Підготовка сучасних фахівців-хореографів передбачає формування міцної теоретичної бази знань, широкого спектру практичних умінь та навичок, необхідних у майбутній професії. Вона має комплексну структуру, будується на основі взаємодії різних видів хореографічної діяльності за умов глибокого й ефективного поєднання інформаційної та творчої функцій навчання [2].

Технологія праці вчителя фізичної культури це мистецтво навчання й виховання, спрямоване на формування особистості школяра, а педагогічна 
технологія - сценарій організації навчальнопізнавальної діяльності майбутніх фахівців із метою опанування обраної професії [5, с. 96].

Учитель фізичної культури - це педагогічний працівник - фахівець із фізичної культури і спорту, який має вищу або спеціальну педагогічну освіту та відповідний освітньо-кваліфікаційний рівень, що організовує та здійснює навчально-виховну роботу 3 учнями закладів загальної середньої освіти з метою формування їх фізичної культури, сприяння гармонійному розвитку особистості, формування позитивних рис характеру, зміцнення здоров'я, вдосконалення фізичної та психологічної підготовки до активного життя.

Процес формування професійної культури в майбутніх учителів спортивно-хореографічних дисциплін, на нашу думку, повинен спрямовуватись на формування та розвиток професійних компетентностей у сфері освіти, вивченні теоретичних та методичних положень, організаційних та практичних інструментів у галузі фізичної культури, спорту та мистецтва, а саме хореографii. Професійні (фахові, предметні) компетентності майбутніх учителів спортивно-хореографічних дисциплін передбачають формування в учнів предметних компетентностей із фізичного виховання, хореографії, медико-біологічних та психологічних основ і технологій розвитку рухових умінь і навичок та фізичних якостей, санітарно-гігієнічних основ діяльності у сфері фізичної культури і спорту. У студентів формується здатність до застосовування сучасних методів й освітніх технологій навчання у фізичному вихованні і мистецтві.

Плануючи зміст підготовки студентів, ми запропонували певний розподіл кредитів за дисциплінами, а саме: цикл загальної підготовки складають дисципліни соціально-гуманітарні (10,8\%), фундаментальні, природничо-наукові та загальноекономічної підготовки (16,3\%); цикл професійної підготовки - (72,9\%). У цілому нормативна частина $-75 \%$, а вибіркова частина - 25\%. Перелік дисциплін, розподіл їх за семестрами, час, відведений на їх викладання, визначається залежно від спеціальності, спеціалізації, кваліфікації майбутнього фахівця.

Проблема наукового обгрунтування змісту хореографічної освіти в закладі вищої освіти, систематизація обсягу навчального матеріалу, створення цілісної системи повноцінної підготовки спеціалістів, розробка нових науково-методичних засад в галузі вищої хореографічної освіти належить до актуальних проблем загальної естетичної культури та вимагає подальшої розробки та вдосконалення теоретичного курсу 3 опанування студентами психолого-педагогічних компонентів у навчальній діяльності.
Педагог-хореограф повинен вміло поєднувати творчу художню роботу 3 навчально-виховною, для чого він повинен мати відповідну підготовку в області хореографії, знати іï теорію і методику, володіти основами теорії музики, сценографіі, добре орієнтуватися в питаннях як загальної, так вікової педагогіки, психології, анатомії, фізіології.

Серед інноваційних методик формування професійної культури майбутніх учителів спортивно-хореографічних дисциплін, інтерактивних методів, форм і прийомів ми визначили такі, як: аудіовізуальний метод навчання; діалог; «дерево рішень»; майстер-класи; конференції; метод аналізу і діагностики ситуації; метод інтерв'ю (інтерв'ювання); метод проектів; моделювання; публічний виступ; семінари, тренінги індивідуальні та групові та ін.

Ефективною формою організації навчання $\epsilon$ проведення майстер-класів, у процесі яких студенти мають можливість ознайомитися з різними формами подачі матеріалу, сформувати уявлення про поліваріативність методик проведення занять, здійснити їх порівняльний аналіз, узагальнення, визначити шляхи формування власної методики викладання хореографічних дисциплін 3 урахуванням передового педагогічного й хореографічного досвіду [8, с. 18].

Головним у підготовці спеціалістів-хореографів, на думку В. Шеремета, є розкриття індивідуальності, виховання хореографа-творця з високим інтелектом, абстрактним і парадоксальним мисленням, можливостями виразу внутрішнього світу через індивідуальну форму руху, а також оволодіння педагогічними прийомами передачі своїх ідей та задумів учням [9, с. 208-209].

Професійні компетентності майбутніх учителів фізичної культури передбачають формування в учнів предметних компетентностей із фізичного виховання, медико-біологічних та психологічних основ і технологій розвитку рухових умінь $\mathrm{i}$ навичок та фізичних якостей, санітарно-гігієнічних основ діяльності у сфері фізичної культури i спорту. У студентів формується здатність до застосовування сучасних методів й освітніх технологій навчання у фізичному вихованні.

На нашу думку, з метою формування професійної культури в майбутніх учителів спортивно-хореографічних дисциплін необхідно застосовувати освітні інноваціі, які полягають у сучасному моделюванні, організації нестандартних лекційних та практичних занять; індивідуалізації засобів навчання; розробці нової системи контролю оцінки знань; застосуванні комп'ютерних, мультимедійних технологій, навчально-методичної продукції нового покоління. Використання мультимедійного супроводу істотно покращує сприйняття й осмислення питань, що розглядаються студентами, 
створює більш комфортні умови для аудиторної роботи студентів та викладачів. Ще одним аспектом застосування інноваційних технологій в освітньому процесі $є$ навчальні програми, які застосовуються, як правило, на практичних заняттях i дозволяють імітувати будь-які процеси та явища або працювати як електронний тренажер.

Висновки. Отже, головне педагогічне завдання освітнього процесу в закладах вищої освіти, що здійснюють підготовку фахівців спортивно-хореографічних дисциплін, є розкриття індивідуальності, виховання спеціаліста, який володіє високим інтелектом, абстрактним і парадоксальним мисленням, способами виразу внутрішнього світу через індивідуальну форму руху, а також педагогічними прийомами передачі своїх ідей, задумів i знань учням-виконавцям у процесі майбутньої професійної діяльності.

Використання інноваційних технологій, комп'ютерної підтримки у викладанні освітніх компонентів дозволяє ввести нове у звичайні форми роботи викладача, сприяє цікавому і повнішому, всебічному розкриттю, зрозумілішому поданню складного навчального матеріалу, значному скороченню навчального часу для успішного засвоєння теми.

\section{ЛІТЕРАТУРА}

1. Бабич М., Вітвицька С. Педагогічна культура викладача вищого навчального закладу. Модернізачія вищзӧ освіти в Україні та за кордоном: збірник наукових пращь. Житомир : Вид-во ЖДУ ім. І. Франка, 2014. С. 77-80.

2. Благова Т.О. Особливості професійної підготовки майбутніх учителів-хореографів у системі педагогічної освіти/ Вісник Житомирського державного університету. Випуск 50. Педагогічні науки. 2010. C. 72-76.

3. Лебідь О.В. Формування професійної культури майбутнього керівника загальноосвітнього навчального закладу в умовах магістратури : монографія. Донецьк : ЛАНДОН-ХХІ, 2013. 226 с.

4. Лола В.Г. Технологічна культура вчителя: сутність i модель формування. Донецьк : ЛАНДОН-ХХІ, 2013. 73 с.

5. Мельнік А.О. Формування готовності майбутніх учителів фізичної культури до позакласної роботи у початковій школі : дис. ... канд.. пед. наук : 13.00.04 «Теорія і методика професійної освіти». Кіровоград, 2015. 246 с.

6. Мойсеюк Н.Є. Педагогіка : навч. посібник. Київ, 2001. 140 с.

7. Радул В.В. Соціальна зрілість особистості : монографія. Харків : Мачулін, 2017. 442 с.

8. Цвєткова Л.Ю. Методика викладання класичного танцю : підручник. Київ : Альтерпрес, 2005.324 с.

9. Шеремета В.І. Освітньо-професійна програма підготовки педагогів-хореографів та їі практична реалізація. Науковий вісник Ужгородського університету: Серія: Педагогіка. Соиіальна робота. Вип. 23. 2011. С. 207-209.

\section{REFERENCES}

1. Babych, M. and Vitvytska, S. (2014). Pedahohichna kultura vykladacha vyshchoho navchalnoho zakladu [Pedagogical culture of a teacher of higher education]. Modernizatsiia vyshchoi osvity $v$ Ukraini ta za kordonom: zbirnyk naukovykh prats. Zhytomyr [in Ukraine].

2. Blahova, T.O. (2010). Osoblyvosti profesiinoi pidhotovky maibutnikh uchyteliv-khoreohrafiv u systemi pedahohichnoi osvity [Features of professional training of future teachers-choreographers in the system of pedagogical education]. Visnyk Zhytomyrskoho derzhavnoho universytetu, no. 50, pp. 72-76.

3. Lebid, O.V. (2013). Formuvannia profesiinoi kultury maibutnoho kerivnyka zahalnoosvitnoho navchalnoho zakladu v umovakh mahistratury: Monohrafiia [Formation of professional culture of the future head of the secondary school in the conditions of a magistracy: Monograph]. Donetsk [in Ukraine].

4. Lola, V.H. (2013). Tekhnolohichna kultura vchytelia: sutnist i model formuvannia [Technological culture of the teacher: the essence and model of formation]. Donetsk [in Ukraine].

5. Melnik, A.O. (2015). Formuvannia hotovnosti maibutnikh uchyteliv fizychnoi kultury do pozaklasnoi roboty u pochatkovii shkoli [Formation of readiness of future physical education teachers for extracurricular activities in primary school]. Candidate's thesis. Kirovohrad [in Ukraine].

6. Моiseiuк, N.Ye. (2001). Pedahohika. Navch. posibnyk [Pedagogy. Teaching. manual]. Kyiv [in Ukraine].

7. Radul, V.V. (2017). Sotsialna zrilist osobystosti: monohrafia [Social maturity of a specialty: monograph]. Kharkiv: Machulin [in Ukraine].

8. Tsvietkova, L.Yu. (2005) Metodyka vykladannia klasychnoho tantsiu: pidruchnyk [Methods of teaching classical dance: a textbook]. Kyiv [in Ukraine].

9. Sheremeta, V.I. (2011). Educational and professional training program for choreographers and its practical implementation. Uzhgorod University Scientific Bulletin: Series: Pedagogy. Social Work, 23, 207-209. 